\title{
Copernican Ideas in Sixteenth Century France
}

HENRY

HELLER

Summary: The French religious wars were marked by intolerance and fanaticism. At the same time the ability of the established church and state to enforce religious and intellectual conformity was seriously undermined. In this atmosphere of crisis and relative intellectual freedom the old Aristotelian and scholastic certainties were shaken. As a result Copernicus' heliocentric theory became a subject of debate between different schools of thought. Conservatives regarded the notion of heliocentricity as a token of religious, moral and intellectual subversion. Neo-Platonists, sceptics and Ramists used the heliocentric idea as a means of attacking philosophical orthodoxy. The intellectual openness of the period prepared the ground for the reception of Galileo's version of Copernicanism at the beginning of the next century.

The age of the French religious wars is a period not celebrated for its 1 tolerance. Bitter polemics between confessional enemies shaped the greater part of public discussion during this period. Despite the occasional intercession of moderate voices, tens of thousands were massacred for religion's sake. Moreover, persecutions were not confined to Catholic or Protestant heretics. In the course of these conflicts the first great wave of witchcraft prosecutions broke out on French soil.

Despite this atmosphere of unbridled religious fanaticism and superstitious hysteria, the late sixteenth century in France was paradoxically a period of remarkable freedom among the intellectual elites. The Roman Catholic Church's ability to enforce ideological conformity collapsed. The coercive power of the monarchy was also gravely weakened by the civil wars. Indeed, 
the royal court found it expedient to promote intellectual and artistic innovation in order to try to bolster its own authority.

The monarchy in fact had traditionally been a qualified friend of intellectual if not religious freedom. During the civil wars its search for social and religious compromise led it to continue to encourage intellectual innovation. In this atmosphere various strands of unorthodox philosophical thought including scepticism, Ramism, Paracelsianism, reformed astrology and neoPlatonism came to the fore. Major innovations in political thought, historical theory, natural philosophy and mathematics marked the period.

It was in this context that the heliocentric theory of Copernicus circulated. For a long time it was thought that these new astronomical ideas had little impact in France prior to the seventeenth century. Indeed, writing at the beginning of the twentieth century, Jean Plattard concluded that Copernicanism had negligible influence in sixteenth century France. ${ }^{1}$ Plattard's view was quite simply mistaken. The accumulated research of the last 90 years has revealed that the Copernican theory was widely known and commented upon by theologians, humanists, scholars and poets during this period. As early as 1550 François Vincent was explaining the Copernican hypothesis to his students at the Collège Lisieux in Paris. During the same decade at Bordeaux Elie Vinet lectured on the Copernican world view to his pupils at the Collège de Guyenne. ${ }^{2}$ Copernicus's ideas were widely disseminated in the French Kingdom. It is notable that Parisian libraries have more copies of the first and second editions of the De Revolutionibus than those of any other European city. There are still more copies of early editions of Copernicus' work in French provincial libraries. ${ }^{3}$ The validity of the theory was hotly disputed by French humanists and scholars becoming enmeshed as it did in the philosophical conflicts of the period. Neo-Platonists, Ramists and sceptics proved to be partially receptive to Copernican ideas or made use of them for their own purposes. At the same time the disputes which did take place helped to make Copernicus' ideas better known, preparing the way for the reception of the more fully developed heliocentrism of Galileo.

In order to discuss the place of the Copernican theory in late sixteenth century France one must make an effort to recall the scientific and religious status of Copernicanism before Galileo. Prior to Galileo the epistemic position of the theory was highly questionable. A physical theory of the universe was considered to have real explanatory force while a mathematical hypothesis or theory such as Copernicus' commonly was taken to be merely a convenient or economical description. Moreover, prior to Galileo empirical proof of the 
validity of the heliocentric view was largely absent. Likewise before Galileo an alternative physics which could support Copernican astronomy did not exist. Hence Copernicanism had a hypothetical status in sixteenth century France that made it somewhat less threatening to conservatives than it subsequently became. It is true that the Copernican hypothesis attracted the hostility of the orthodox from an early date. But the kind of overwhelming bureaucratic, political and religious power mobilized to crush Galileo did not obtain in France during the religious wars. Instead the Copernican hypothesis became a kind of sounding board against which the various philosophical and religious currents of the time were reflected.

For a long period the attitude of Calvin toward Copernicus was based on conjecture. Liberal-minded historians of thought like Andrew Dickson White in the nineteenth century and Bertrand Russell in the twentieth century simply assumed that Calvin had condemned the heliocentric theory. The evidence for this assumption did not exist. In the absence of such proof the Copernican expert Edward Rosen went so far as to argue not too long ago that Calvin had never read Copernicus and was unaware of his views. ${ }^{4}$ The matter was apparently settled in 1971 when the Calvin scholar Richard Stauffer published his discovery of an explicit reference to Copernicus' theory by Calvin. ${ }^{5}$ Stauffer found this allusion in Calvin's eighth sermon on 1 Corinthians 10 and 11 which was probably preached in 1556 . There Calvin denounces those who defend the Copernican view as those who are negative or inconsistent in spirit. According to Calvin, partisans of the Copernican view seek to pervert the order of nature. What White and Russell had assumed Stauffer proved to be true: Calvin rejected the Copernican theory no less than had Luther.

Several points have since been made which perhaps somewhat mitigate Calvin's disapproval of those who followed Copernicus. It has been argued that understanding Calvin's ultimate position with respect to Copernicus awaits a more exhaustive search of his writings and that his comments need to be understood in their full context. Furthermore, it is noted that Calvin did not invoke the Scripture against the Copernican view as did Luther. This made it possible for Calvinists to be able to adjust the Scriptural position to agree with scientific truth. Certainly in the sixteenth century it is understood that French Calvinists are to be found on both sides of the Copernicus debate. Still, when all is said and done, it is quite likely that Calvin unequivocally condemned the Copernican theory. This would only be consistent with his own lifelong quest for absolute certainty. In this context his charge of inconsistency against the Copernicans has to be taken as a reflection of his own passionate dogmatism. 
The Huguenot poet Guillaume de Saluste du Bartas, evidently following in Calvin's footsteps, continued to champion the traditional geocentric view. Du Bartas based his reassertion of a traditional world view on the Bible and the philosophical assumptions of Plato and Aristotle. ${ }^{6}$ His La Sepmaine uses the story of creation as a means of restating the fundamental truths of a Christian world view. Du Bartas was a convinced Huguenot and many of his fellow Calvinists considered his poem a distinctively Calvinist creation. Yet the philosophical foundations of the work were sufficiently traditionalist that it came to be widely admired even in Roman Catholic circles. ${ }^{7}$

Du Bartas takes up the Copernican view of the world in the Fourth Book of La Sepmaine. ${ }^{8}$ Having elaborated the basic ideas of Copernicus in poetic language, Du Bartas condemns those who champion them as frenetic and errant minds who are unable to sail "the peaceful waves of a common sea." The intellectual arguments of the Copernicans are not confuted. Instead they are condemned as intellectually inconstant and deviant. ${ }^{10}$ The Calvinist humanist and historiographer Simon Goulart wrote a commentary on Du Bartas' epic which was repeatedly reprinted with it. In it he elaborates on Du Bartas' censure of the Copernicans by denouncing them as framers of paradox, i.e., as among those who delight in constructing literary and philosophical conundrums for their own sake and who are therefore uninterested in truth. Accordingly, in his view, their ideas are not to be taken seriously. ${ }^{11}$

Calvin, Du Bartas and Goulart all criticized the motivations of the Copernicans rather than their ideas. Pierre de Dampmartin is an example of a Calvinist who actually offered an intellectual argument against Copernicus. A moderate Huguenot, Dampmartin was from Languedoc or Gascony and began his career in the service of Jean d'Albret. ${ }^{12}$ In 1572 he entered the employ of the Duke of Alençon who made him procureur général in Languedoc and in 1585 sénéchal of Montpellier. That same year Dampmartin published De la connaissance et merveilles du monde et de l'homme. ${ }^{13}$ In it he defends the geocentric universe on the basis not only of Aristotle but also on the authority of Scripture. But for good measure he cites the standard argument that the absence of stellar parallax suggests the immobility of the earth. ${ }^{14}$

While there obviously were orthodox Protestants including Calvin himself who were unable to accept the notion of a heliocentric universe there was in fact no unanimity in this camp. Du Bartas' attack on Copernicus, for example, did not go unanswered. In 1599 the Calvinist Christophe de Gamon published a reply to Du Bartas entitled La Semaine ou creation du monde contre celle du Sieur du Bartas..$^{15}$ Gamon, who was trained in pharmacy, 
medicine and natural philosophy, spent his life in the Vivarais. ${ }^{16}$ Unable to pursue a public career because of his fragile health, he lived in semi-retirement devoting himself largely to poetry. Indeed, his work acquired a certain reputation especially among his fellow Calvinist notables. In his own $\mathrm{La}$ Semaine he denounces Du Bartas for his attack on the incomparable honour of the learned Copernicus. ${ }^{17} \mathrm{He}$ defends Copernicus by arguing that his hypothesis better fits the observed data than the conceptions of his predecessors. ${ }^{18}$

But the most interesting defense of Copernicus by a Calvinist was made by Jacques Besson. ${ }^{19} \mathrm{He}$ was born at Colombière, a village in the valley of Oulx in Dauphiné. At some point he moved to northern Italy where he studied engineering and physics, the latter at the University of Bologna, Ferrara or Padua. ${ }^{20}$ By 1557 he was resident in Lausanne where he undertook to install pumps to supply the town with water. The next year he married in a ceremony presided over by Jean Calvin himself. Received a habitant of Geneva he became one of the scores of evangelical ministers who were dispatched from Geneva to proselytize the French Kingdom at the beginning of the religious wars. Between 1562 and 1564 , Besson served as a minister to the Calvinist congregation of Villeneuve-le-Berg in the Vivarais. Having quarrelled with the elders of the church there he moved to Lyon, then Orléans and finally to Paris where he died in 1573.

Besson appears to have been affected by the discussions of scientific method current in the Italian universities. Thus, many of Besson's contemporaries criticized the Copernican view as a mere hypothesis. On the other hand, Besson praised Copernicus for making the hypothetical approach an intrinsic part of his method. Besson was chiefly interested in discovering and applying useful types of knowledge. One of his concerns was with uncovering hidden underground sources of water. In particular he sought to improve upon the traditional techniques still used by farmers and engineers which too often led to fruitless investment. Besson's approach represented a rejection of the empiricism which governed existing practice. This is suggested by the title of Besson's treatise on the subject entitled L'art et science, de trouver les eaux et fontaines cachées soubs terre, autrement que par les moyens vulgaires des agriculteurs et architectes (1569). ${ }^{21}$ Given the prevailing hit-or-miss practice of vulgar empiricism Besson proposed a new procedure for searching for water which brought together empirical facts with first causes. According to Besson, bringing the two together in this way was more demonstrative than each taken separately. Stressing the novelty and utility of this approach, he compares it to the method of Copernicus which had led the latter to the heliocentric view of the universe. ${ }^{22}$ 
Besson here implicitly endorses the heliocentric world view and explicitly champions the combination of empirical data with theory that likely echoes the approach to be found in the teaching of natural philosophy in the northern Italian universities. Clearly the fact that Besson held these views indicated that there was no inherent antagonism between Calvinist theology and science. On the contrary, a review of the development of French science during the second part of the sixteenth century suggests a close affinity between scientific innovation and Calvinism. Recent research has demonstrated that despite the disorder of the religious wars the late sixteenth century was a remarkably fertile period in the history of science. Important advances occurred in natural history, medicine, chemistry, and mathematics. ${ }^{23}$ Particularly notable was the progress made in the development of a new empirical and even experimental approach to the study of nature. Prominent among those who contributed to this movement were such well-known Calvinist sympathizers as Guillaume Rondelet, Jean Pena, Mathieu l'Obel, Ambroise Paré and Pierre de la Ramée. But also important were a number of more obscure French Calvinist physicians and chemists like Roch Le Baillif, Sieur de la Rivière, and Joseph Duchesne who elaborated on the teachings of Paracelsus. Not every scientific advance during this period can be attributed to the Calvinists. Nonetheless, as elsewhere in Europe, it does seem that sympathy for the teachings of Calvin and a desire to reform or create new knowledge in order to improve society went hand-inhand. ${ }^{24}$

Pierre de la Ramée(Ramus) who was murdered in the Saint Bartholomew's Day Massacre was the most outstanding figure in French philosophy and science in the second half of the sixteenth century. His attempts to reform the liberal arts and the teaching of philosophy had a wide impact in France and elsewhere in Europe. Particulary notable were his calls for a methodological reform in natural philosophy which would make it more empirical and practical, tying it closely to technology.

Ramus, unlike most other French students of astronomy, had direct ties to the leading proponent of Copernican astronomy Georg Joachim Rheticus. ${ }^{25}$ Rheticus had been Copernicus' only real student and was instrumental in arranging the publication of the De revolutionibus in 1543. He continued to promote Copernicus' views from his chair at the University of Krakow. In 1563 Ramus wrote to Rheticus telling him of his plan to reform the liberal arts while admitting that the reform of astronomy was beyond his capacities. Accordingly, he invited Rheticus to Paris to discuss how a reform of astronomy could be made part of this larger project. Four years later Ramus expressed the 
hope that there would arise in Germany a philosopher and mathematician who could bring about such an astronomical reform.

Ramus declared Copernicus to be the greatest astronomer of the modern age. Nonetheless, he was uncomfortable with the idea of an earth in motion. Moreover, despite the fact that Copernicus believed his heliocentric system to be a physical model of the earth Ramus claimed that like that of Ptolemy's the Copernican system was too hypothetical. By this he meant that its mathematical component was not sufficiently subordinated to a convincing physical model of the universe. A convincing theory is one in which the necessary mathematical component is subservient to a physical model of the heavens.

Ramus' opinion of Copernican astronomy is of a piece with his overall view of the liberal arts. He argued that the current artificial systems in logic, rhetoric, geometry, etc. were founded on arbitrary conventions and that they should be based instead on practice. It is the unsophisticated practical knowledge of skilled craftsmen rather than the abstract conventions of theoreticians which are closest to nature. Accordingly, Ramus believed that all astronomical hypotheses were no more than human conventions which could not conform to nature as immediately observed by the mathematical practitioner and as it was in itself. Ramus' scientific method thus appears to have been based on a rather simple-minded empiricism. It is in sharp contrast, for example, with the hypothetical-deductive approach of Besson who considered Copernicus' heliocentric conception to be what he characterized as a first cause, i.e., an assertion of an ultimate physical truth which ought to be verified by empirical confirmation.

Ramus' closest associates showed an openness toward the Copernican viewpoint which was greater than their master. Jean Pena, a native of Moustiers in Provence, entered the Faculty of Arts at the University of Paris in 1549 at the age of 17, the mathematician Omer Talon directing his studies. ${ }^{26}$ By 1554 he was teaching mathematics and astronomy at Ramus' Collège de Presles. Through the support of Ramus he was appointed royal reader in mathematics.

Pena's enthusiasm for Copernicus emerges in his long dedicatory epistle to the Cardinal of Lorraine of his translation of Euclid's Optics. There he characterizes Copernicus as "most famous" and "a man of certainly marvellous sagacity." 27 No more than Ramus did Pena accept the Copernican hypothesis without reservation. Yet he did allow that the position of the earth certainly changed over time and that from the point of view of optics the heliocentric perspective was as plausible as the geocentric. ${ }^{28}$ Basing himself on observations he denied Aristotle's belief in the existence of the celestial 
spheres and the latter's claim that the comets belonged to the sublunar realm. In these latter respects Pena may have helped shape the views of Tycho Brahe.

Ramus' extreme philosophical realism was not necessarily shared by members of his inner circle. Omer Talon, perhaps Ramus' closest associate, for example, showed himself to be much more favourably disposed to the Copernican hypothesis than was Ramus himself. A deeply learned mathematician Talon appears to have better appreciated the epistemic value of the coherent mathematical language of Copernicus' conception than did Ramus.

Talon was born in 1510 into a rich peasant family from Rosières in Picardy. ${ }^{29}$ Likely he matriculated into the Arts Faculty of the University of Paris in 1534 receiving an M.A. in 1536-1537. After teaching at several different collèges he joined Ramus at the Collège de Presles in the 1540s.

Talon refers to Copernicus' theory in book II of his Academicarum questionum a work published only seven years after the appearance of $D e$ Revolutionibus. He concludes that Copernicus has revived the heliocentric theory showing that it better fits the observed data than the notion of a geocentric universe ${ }^{30}$ For Talon mathematical simplicity appears to have been more of a criterion of scientific truth than for Ramus.

The appeal of Copernicanism for Talon lay not only in its mathematical coherence but also in its challenge to the Aristotelian orthodoxy. Talon adopts the view that sensory knowledge cannot provide us with unquestionable truth. Contrary to Aristotelian dogmatism, Talon supports a probabilistic view of truth rooted in academic scepticism. In this respect the apparently hypothetical character of the Copernican view had obvious appeal..$^{31}$ Clearly Talon's philosophical position differed sharply from that of his master Ramus who held to a realist notion of natural philosophy. What united the two men was a commitment to educational reform based on a union of eloquence and wisdom and to the ideal of free philosophical inquiry unencumbered by the presuppositions and prejudices of Aristotelianism or other dogmatic schools of thought.

A close affinity developed between academic scepticism and Copernicanism. Defense of the Copernican hypothesis became a way in which sceptics could cast doubt on the certainty of traditional natural philosophy. The deployment of the Copernican world view in this way is evident already in Guy de Bruès' Dialogues contre les nouveaux academiciens (1557), likely the earliest discussion of sceptical philosophy to appear in the French vernacular. ${ }^{32}$ Born between 1526-1536 Bruès was the scion of a family of jurists from Nîmes. He was connected both with Ramus and the Pléiade. The Dialogues consist of three conversations, the first on epistemology, the second on ethics 
and the last on law. The interlocutors are Pierre de Ronsard, Jean-Antoine de Baif, Guillaume Aubert and Jean Nicot who were all connected to the Pléiade. Although it is difficult to know the degree to which he actually embraced scepticism, Baif in the opening dialogue nonetheless takes the lead in pointing out the limits of human reason. Conceding that perhaps the senses are reliable, he nevertheless asserts that scientists and philosophers disagree about everything and that their views are not objective but only their own opinion.

It is in the context of this first dialogue that Baif contrasts the views of Copernicus and his followers with those of the established authorities Plato, Aristotle and Ptolemy. ${ }^{33}$ The latter believe that the earth is immobile and that the heavens move while Copernicus asserts the contrary. Baif argues for the Copernican position on the rather surprising grounds that the heavens are in fact infinite. It has been pointed out that this is not a Copernican position but rather a revival of a scholastic viewpoint. ${ }^{34}$ According to Baif, something that is infinite is inherently immobile. Consequently if the heavens do not move it must be the earth which is mobile. He goes on to argue that the earth must occupy a middling position with respect to the other planets based on the differences of the periodic motions of the inner and outer planets. Baïf is then led to the conclusion not that Copernicus is right and the Ancients wrong, but that the science of astronomy like other forms of knowledge has no certainty.

Baif serves as a mouthpiece through which Bruès is able to develop the sceptical position. The extent of Bruès' own commitment to scepticism is the subject of debate. ${ }^{35}$ Likely influenced by Bruès, Montaigne adhered to the sceptical point of view in a much more explicit fashion. Montaigne's view of Copernicus is to be found in Chapter XII, Book II of his Essais. ${ }^{36}$ Like many of his contemporaries Montaigne underplays the novelty of the Copernican perspective. According to him, Copernicus has revived an astronomical perspective already current in Antiquity, but one which fits the accumulated astronomical data as well or better than that of Ptolemy. But Montaigne's attraction to the Copernican theory transcends the issue of the relative merits of the heliocentric or geocentric theory. For Montaigne the real significance of Copernicus' accomplishment lies in the fact that the latter has been able to put into doubt long-held and apparently unshakable truths. Copernicus' challenge to the Ptolemaic view ought to encourage us to be sceptical of all received knowledge. At the same time Montaigne suggests that Copernicus' challenge to received dogma ought not to cause us to abandon the search for new truth. Rather it should make us realize its limited and contingent nature. This attitude is implied in Montaigne's conclusion in which he notes that over the course of 
time a new third opinion is likely to appear which will probably overthrow those now existing. Copernicanism is seen as superior to Ptolemaic astronomy, but something less than ultimate truth. Indeed, the debate between the proponents of the two world systems should serve as a warning against the quest for absolute knowledge.

Bruès' Dialogues contre les nouveaux academiciens portrayed Baïf as a proponent of the sceptical philosophy. But he is better known as the founder of the Neo-Platonic Academy of Poetry and Music. ${ }^{37}$ Baif's Academy was founded in 1570 under the aegis of Charles IX. Its creation was part of a concerted effort by the monarchy to reconstruct its own political authority by taking the lead in educational, technological and scientific innovation. The Academy's purpose was to advance the study of the different sciences while uniting these rational disciplines through the cultivation of the inspired arts of poetry and music. The Academy attracted the support of poets, humanists and courtiers who were sympathetic to Neo-Platonism. Its humanist and NeoPlatonist program and somewhat irenic attitude toward the Calvinists aroused the suspicion of conservatives in the University of Paris.

We know from Bruès of Baïf's interest in Copernicus. But more so than Baiff, the poet and scholar Pontus de Tyard was the member of the Academy most interested in astronomy. Deeply schooled in the Ptolemaic and Aristotelian world view he nevertheless voiced a certain openness toward the Copernican position. ${ }^{38}$ Tyard's interest in Copernicus was in part the outcome of a Neo-Platonist heliocentrism. But it also arose out of concern to promote a reformed astrology. ${ }^{39}$ Astrology had come under attack in the late fifteenth and early sixteenth century because it was seen to conflict with Christianity. Toward the middle of the sixteenth century astrology once again became the subject of dispute. In addition to the issue of its relation to religion its status as a form of knowledge came into question. On the one hand, there were those who aspired to the creation of a reformed astrology which would be mathematical and accord with the principles of natural philosophy. On the other hand, there were others, who, influenced by Neo-Platonism and the Hermetic philosophy, continued to be under the spell of the magical and the occult. Tyard's Mantice, the first edition of which appeared at Lyon in 1558, took the side of the reformed astrology. But such a reformed astrology required more accurate astronomical tables. Copernicus' De Revolutionibus was the point of departure for the elaboration of these new tables and ephemerides. Among these were the Prutenic Tables of Erasmus Reinhold (1551), the Ephemerides of Johannes Stade (1556) and those of Tyard himself (1562). 
In the Premier Curieux Tyard elaborated the theory of Copernicus and stressed the ingenious character of his arguments. Especially valuable, according to Tyard, were Copernicus' observations. On the other hand, he left the question of the truth of the theory open. Emphasizing an argument which can be extracted from the De Revolutionibus itself, he insisted that the truth of the theory would not put into question the established physics of the earth. Yet in the same work he at least entertained the idea that motion more properly belongs to a corruptible body like the earth than to the incorruptible heavens. In the Mantice he welcomed the notion that the heavenly bodies might be inhabited by living beings and that the earth might be a star along with the other stars in the universe. ${ }^{40}$ Tyard thus plays with the Copernican world view without fully accepting it. Attracted to its intellectual novelty and the elegance of its demonstrations, his own metaphysical and perhaps spiritual assumptions prevented him from accepting Copernicus without reservation.

The relationship between an interest in judicial astrology and Copernicus is confirmed by the example of the court astrologer Augier Ferrier. Ferrier defends Copernicus' heliocentricism not on the basis of the truth of the theory, but on the grounds of the more accurate observations that it allows. Ferrier was born near Toulouse (ca. 1513) and received his doctorate in medicine at the University of Montpellier in $1540 .{ }^{41}$ Having published a treatise on the plague (1548) his next work Jugements astronomiques sur la nativité (1549) gained him entry into the entourage of Catherine de Médicis as first physician. At court he became celebrated both for his cures and his horoscopes. He also interested himself in the interpretation of dreams, including those of divine or diabolical inspiration. At the beginning of the Civil Wars he returned to Toulouse where he was eventually appointed professor of medicine.

Bodin had attacked the practice of judicial astrology. Ferrier mentions Copernicus in the course of responding to Bodin's attack. ${ }^{42}$ Like Tyard he stresses the greater certainty of astronomical observations made possible by Copernicus' heliocentrism. Previous geocentric theories had yielded imprecise or even false calculations. The heliocentric viewpoint enabled Copernicus to obtain more exact calculations. On the other hand, Ferrier no more than Tyard affirms the truth of the Copernican theory. Instead he falls back on the notion of the purely hypothetical character of Copernicus' position. Indeed, Ferrier argues that Copernicus had disclaimed the truth of his hypothesis regarding it as a pure contrivance devised to get more exact calculations. ${ }^{43}$

The Neo-Platonist Tyard's philosophically and theologically based resistance to Copernicus' theory is echoed in the thought of the aristocratic 
churchman François Foix de Candale. Candale, who spent most of his time at Bordeaux, gained a reputation as an outstanding experimenter and observational astronomer. ${ }^{44}$ At the same time his thinking like that of Tyard's was strongly coloured by the influence of Neo-Platonic and Hermetic elements. Typical of such a position Candale espoused a strongly heliocentric cosmology considering the form of the sun to be divine light and therefore worthy of veneration as an expression of God's divinity. ${ }^{45}$ According to Candale, the sun was the primary agent of God designed by Him to manifest all corporal things to man. Yet he entirely accepted the framework of Ptolemaic observational astronomy as the basis of his astronomical observations. Such an approach was being rejected even by the opponents of Copernicus' heliocentrism. More often than not the latter rejected the cosmological implications of Copernicanism while nonetheless being prepared to acknowledge the superiority of the latter's approach for observational purposes. Candale did not even go that far.

Candale concluded that, however central to the universe the sun might be philosophically, geometrically the earth must be considered the immobile centre of the universe. Copernicus work was "most beautiful" and perhaps philosophically correct, yet his view could not be considered a correct geometrical representation of the universe. Beyond this difference over geometrical procedures it seems that the difficulty lay with having to accept the philosophical and religious implications of a heliocentric theory. ${ }^{46}$ But if Candale despite his Neo-Platonism stood opposed to Copernicanism and Tyard at best equivocated there was one Neo-Platonist Giordano Bruno who was prepared to draw out the radical cosmological implications of Neo-Platonism. Bruno's claims for the truth of Copernicanism first came to the fore during his sojourn in England (1583-1585). But Edward Gosselin argues that Bruno's commitment to Copernicanism really began during his initial residence in France (1583-1585).$^{47}$ Bruno then defended these ideas in a dramatic debate at Oxford in 1583 and elaborated on them in a series of works which he published while in England. He continued to champion these notions on his return to France going so far as to restage the Oxford debate at the University of Paris (1586) ${ }^{48}$

Frances Yates, the great student of Bruno of the last generation, believed that Bruno's adherence to Copernicanism was rooted in his hermeticism. ${ }^{49}$ The heliocentric universe is one in which man can manipulate celestial influences more easily than in a geocentric cosmos. But as Robert Westman and Ernan McMullin have argued it is Bruno's radical Neo-Platonism with its notion of plenitude rather than his hermeticism which led him to reject geocentricity and to assert the notion of a heliocentric world as part of a an infinite universe. ${ }^{50}$ 
Yates may have exaggerated the degree of Hermetic influence on Bruno's thought. On the other hand, her portrayal of Bruno as a proponent of the irenic religious policies of Henri III seems convincing -- more convincing than the recent suggestion that he became an agent of the English Queen. ${ }^{51}$ Indeed, the loss of the support of Henri III appears to be directly connected with Bruno's discomfiture during the well-known debate at the University of Paris in $1586 .{ }^{52}$

Despite his espousal of heliocentrism Bruno's astronomy was far from being identical to that of Copernicus. Believing the planets to be animate bodies, Bruno took the view that they determine their own orbits which are not necessarily circular. Moreover, Bruno like Ramus distinguishes between accounting for the causes of planetary motion and mathematical description of them, the latter procedure being merely computational. According to Bruno, Copernicus in the end was more a mathematician than a philosopher of nature. Nonetheless, Bruno celebrated Copernicus as anticipating his own philosophy of the universe with its notions of animate matter and infinitude.

Bruno's cosmological radicalism was in effect disowned by the monarchy. The latter's ultimate preoccupation was the promotion of ideas which would foster the restoration of civil peace and its own authority. From the perspective of political theory no one played a greater role in this respect than Jean Bodin. The restoration of intellectual and political stability was in fact a central concern in Bodin's philosophy. Accordingly, it is not surprising that Bodin viewed the Copernicanism as destabilizing and disruptive. The danger of subversion that Bodin perceived to be inherent in Copernicanism is reflected in the fact that he repeatedly attempted to refute it. Bodin attacked Copernicanism on at least three occasions in the Six Livres de la Republique(1576), ${ }^{53}$ in the pseudonymous Apologie pour la Republique de Jean Bodin (1583), ${ }^{54}$ and in the Universae Naturae Theatrum. ${ }^{55}$ Each successive discussion represented a more detailed and elaborate attempt to refute the Copernican world view.

Bodin's rejection of the Copernicus' hypothesis was in part based on his own astronomical theories. ${ }^{56}$ These views were founded on Jewish sacred writings as well as the calculations of the Alphonsine tables. On this basis Bodin postulates the existence of ten celestial orbs which circle the earth. Like Bruno, Bodin believed that since the planets are animate and intelligent bodies they determine their own orbits. Rejecting the Aristotelian and Ptolemaic assumption of perfectly circular motion, Bodin claimed that the planets follow oval orbits. As was so commonly the case mathematics was seen as useful and even necessary but as essentially descriptive rather than determinative of planetary motion. 
Having rejected Aristotelian astronomy in favour of his own conceptions Bodin nonetheless makes the physics of Aristotle the basis of his philosophical attack on Copernicus. In accord with Aristotle he insists that each body of matter must have a single natural motion. But Copernicus attributes four natural motions to the earth. ${ }^{57}$ Bodin argues that if one accept these four motions as natural to the earth one in effect negates physics itself. Reinforcing this argument Bodin raises the standard objections that if the earth rotated arrows would travel further in one direction than another and that balls would not fall perpendicularly from a tower to the ground. His final argument has to do with what he considers the asymmetry of behaviour of so-called heavenly bodies in the Copernican scheme. Under this view the sun would be at rest while the planetary bodies composed of similar stuff would be in motion.

Bodin's cosmology despite its deviation from orthodox Aristotelian astronomy is nevertheless rooted in a profoundly traditional physics. But such views were themselves based on a deeply conservative social and intellectual outlook. He himself employed a method which was designed to reunite and reassemble both the natural and the social world. From his perspective Copernicus' resolutive procedures appeared to be inherently inimical to this project..$^{58}$ Bodin's distaste for the radical implications of Copernicus' view is seen in his reaction to the latter's conception of the earth's orbit as eccentric to the centre of the sun. Copernicus had noted that this eccentric position of the earth might help explain change of governments and the ruin of kingdoms. ${ }^{59}$ Such a view implied that political instability was an intrinsic feature of all earthly political institutions. As a result Bodin was at pains to reassert that astrological influences by common consent of all students of the heavens were the outcome of celestial and not earthly influences. The idea that events at this level could be determined by an earthly physical cause rather than a heavenly one was apparently unacceptable. No less disturbing was the notion of a permanently destabilized earth making for permanent political instability. Moreover, Bodin would not be put off by the rationalization that the Copernican view was after all merely a hypothesis. In response to this argument he quite correctly pointed out that Copernicus in fact had tried to demonstrate the truth of the heliocentric theory. According to Bodin, this showed that Copernicus really believed in the physical truth of his theory. ${ }^{60}$

Bodin's attack on Copernicanism in the Universae Naturae Theatrum (1596) reflects the fact that the issue of the acceptance or rejection of the theory was far from decided at the end of the sixteenth century. Indeed, the period we have been reviewing was one of great intellectual confusion marked by the 
breakdown of the old intellectual paradigm and the absence of a new one. NeoAristoteleanism, Neo-Platonism, Stoicism, Epicureanism, Ramism, Scepticism and Paracelsianism competed with one another for people's intellectual allegiance. Under such circumstances Copernicanism became a kind of intellectual shuttlecock which was batted back and forth between contending schools of thought. In this context we can discern certain signs that augured well for the future of the Copernican viewpoint. The attraction of the sceptics toward Copernicanism helped to identify the new astronomy with the developing challenge to orthodox and dogmatic thought. Besson's appreciation of Copernicus' method represented a step beyond the naive empiricism which was shared by Aristotelians and Ramists. Finally, Neo-Platonist notions of plenitude as embodied in Bruno's writings helped to undermine the anthropomorphic and closed view of the universe of the Aristotelians.

Nevertheless, the obstacles to the acceptance of the Copernican world view continued to be formidable. Prejudice in favour of a naive common sense of the world remained quite strong. It was underlaid by a persistent anthropomorphism and the survival of important elements of animism. With the possible exception of Talon there was a virtually complete failure to understand mathematics as the language of nature. Indeed, there continued to be a strong bias against this view. Finally, the weakness of empirical confirmation of the Copernican view and of a physics which could support it ought to be reiterated.

These defects were remedied in part by the work of Galileo. Appreciation of his work in France was enhanced at the beginning of the seventeenth century by the sudden emergence of observational astronomy, the rapid development of abstract mathematical thought and the appearance of an informal community of natural philosophers interested in scientific innovation. ${ }^{61}$ But the emergence of a new intellectual paradigm in the form of seventeenth century rationalism in close association with the consolidation of the secular bureaucratic state is what perhaps best explains the eventual triumph of Copernicanism. ${ }^{62}$ The development of rationalism in part was a response and accommodation to the Copernican world view. At the same time it represented a powerful intellectual reinforcement of it. Finally it should be noted that the polarization of opinion in the Roman Catholic camp against Copernicanism tended to raise its stock among Calvinists and even among more worldly Gallicans.

In concluding this study of the influence of Copernican ideas on late sixteenth century French thought it would be useful to try to locate this essay in its contemporary historiographical setting. In the first place it should be 
recalled that the French debate over the Copernican world view unfolded in the midst of a broader discussion of new methods of natural philosophy and amid a rising tide of interest in the empirical study of nature that took place during the religious wars. Appreciation of this wider background in which the argument over Copernicus was set suggests the need to modify the dating of the beginnings of the new science in France. At present it is assumed that the dawn of the new philosophy there is to be found in the early decades of the seventeenth century. Recent scholarship implies a point of origin at least a generation earlier. Moreover, it suggests a connection between these developments not only with political and religious change, but also with transformations in the technology and the economy. ${ }^{63}$ As such this study of Copernican influence in Renaissance France is a reflection of the contextualized approach to the history of science which has become increasingly prominent in the last few decades. ${ }^{64}$

Contrary to the internalist view of scientific development, the contextual perspective assumes that the history of science is not concerned with the progressive discovery of eternal truths, but is the reflection of an unceasingly mutable human culture and society. In a sense a changing humanity receives the kind of answers from nature that it continually asks of it. The questions that are posed at any particular moment are the product as much of a particular configuration of ideological tendencies, philosophical opinions, techniques and instruments, institutions and political and social forces as of the existing body of scientific knowledge. In the case of early modern science the contextualist viewpoint, for example, tries to show that there were different national preoccupations and concerns that conditioned the development of science in particular countries. ${ }^{65}$ Certainly we have seen that in France the breakdown of institutional control over ideas during the religious civil wars provided a relatively open intellectual environment which encouraged debate about the Copernican idea.

As this paper has attempted to demonstrate the contextualist perspective takes for a given that the scientific ideas of the early modern period were embedded in a complex and contradictory tissue of philosophical, religious and magical currents. ${ }^{66}$ The triumph of certain scientific concepts over others, furthermore, was by no means a product simply of reason and experiment. Scientific argument embodies itself in a discourse which uses the arts of rhetoric and devices of language to try to win over its intended audience. In the case of Copernicus recent scholarship has demonstrated the artful language into which the astronomer cast his arguments in an effort to convincingly address the ecclesiastical-political circles which he was attempting to per- 
suade.$^{67}$ In the French milieu the heliocentric idea becomes a kind of metaphor which was invoked variously by those who practised the language of Platonized metaphysics, utilitarianism, mathematics and sceptical paradox.

At the same time the birth of modern science was very much a product of the struggle to publish and render accessible a Renaissance tradition of occult and secret learning. ${ }^{68}$ Certainly in sixteenth century France Ramus was an important pioneer in this effort, however debatable his interpretation of scientific method might have been. Indeed, the institutional and political context in which scientific ideas were disseminated was critically important to their acceptance or rejection. In this respect the relatively open intellectual climate of the French religious wars was certainly conducive to the discussion of Copernicanism. Its institutionalization would occur in the quite different environment of the next century. Scientific ideas then are the product of definite cultural and social environments. However, it should be emphasized that we reject the view that has taken hold in certain quarters that knowledge including natural science is only the product of cultural and social relations. The material reality of nature is a fundamental and inescapable aspect of the context in which scientific ideas are generated setting the limits of scientific argument.

\section{University of Manitoba}

\section{Notes}

1. "Le système de Copernic dans la littérature française du XVI' siècle," Revue du Seizième Siècle, I (1913), 220-237.

2. Henri Busson, Le rationalisme dans la littérature française de la Renaissance (Paris: J. Vrin, 1957), pp. 257-258.

3. Owen Gingerich, "The Great Copernican Chase." American Scholar, 49 (1986), p. 83.

4. Scholarly opinion on Calvin's attitude to Copernicus is reviewed in Robert White, "Calvin and Copernicus: The Problem Reconsidered" in Richard C. Gamble, ed. Calvin and Science: Articles on Calvin and Calvinism (New York: Garland, 1992), pp. 131-132.

5. "Calvin et Copernic," Revue de l'histoire des religions, 179 (1971), 31-40.

6. James Dauphiné, Guillaume de Saluste du Bartas, poète scientifique (Paris: Les Belles Lettres, 1983), pp. 39-75.

7. Dauphiné, Ibid.,pp. 17-29. For a discussion of the relationship between Copernicanism and religious authority in the sixteenth century, cf. Robert S. Westman, "The Copernicans and the Churches" in David C. Lindberg and Ronald L. Number, eds., God and Nature: Historical Essays in the Encounter Between Christianity and Science (Berkeley: University of California Press, 1986), pp. 76-113. 
8. Les Oeuvres de Guillaume de Saluste, seigneur du Bartas (Paris: Pierre Huet, 1583), ff. 164․-65". Cf. Dauphiné, Ibid., pp. 100-114; James Dauphiné, "Palingenius, Du Bartas, de Gamon, De Rivière et le système de Copernic," in R. J. Schoeck, ed. Acta Conventus NeoLatini Boloniensis: Proceedings of the Fourth International Congress of Neo-Latin Studies, Bologna, 26 August to 1 September 1979 (Binghamton: Medieval \& Renaissance Texts \& Studies, 1985), pp. 27-33.

9. Dauphiné, Guillaume de Saluste du Bartas, p. 101.

10. A similar view of the advocates of Copernicanism is taken by emulators of Du Bartas, like Miles de Norry, Joseph Du Chesne and Isaac Habert. Cf. Dauphiné, Ibid., pp. 103-104.

11. Goulart compares them to the Machiavellians who for the sake of paradox have written apologetics in favour of tyranny. Cf. Les Oeuvres de Guillaume de Saluste, f. 165".

12. Roman d'Amat, "Pierre de Dampmartin," in J. Balteau et al., Dictionnaire de biographie française (Paris: Letouzey et Ané, 1933), vol. X, p. 74 (hereafter DBF). Dr. Hoefer, ed. Nouvelle biographie générale (Paris: Firmin Didot, 1857-1866), vol. XII, pp. 891-893.

13. (Paris, 1585).

14. Ibid., ff. $3^{\mathrm{v}} \cdot-4^{\mathrm{r}}$.

15. (Geneva, 1599).

16. Roman d'Amat, "Christophe de Gamon," $D B F$, vol. XV, p. 315; Eugène et Émile Haag, La France protestante (Paris, 1855, Geneva, 1966), vol. V, pp. 209-213; A. Mazon, Notice sur la vie et les oeuvres d'Achille de Gamon et de Christophe de Gamon d'Annonay au Vivarais (Lyon, 1855).

17. Ibid., p. 114.

18. A. M. Schmidt, La poésie scientifique en France au seizième siècle (Paris: Albin ichel, 1938), p. 316.

19. Denis Hilliard, "Jacques Besson et son "Thêâtre des instruments mathématiques"”, Revue Française d'Histoire du Livre, nouv. série 48 (1979), 5-38; Hilliard, "Jacques Besson et son 'Théâtre des instruments mathématiques': recherches complémentaires," Revue Française d'Histoire du Livre, nouv. série 50 (1981), 47-77; Eugénie Droz, Chemin de l'hérésie (Geneva: Droz, 1976), Iv, 271-372; Alexander Keller, “A Manuscript Version of Jacques Besson's Book of Machines," in Bert S. Hall and Delno C. West, eds., On Pre-Modern Technology and Science: A Volume of Studies in Honor of Lynn White Jr. (Malibu, CA: Undena, 1976), pp. 75-103; Keller, "The Missing Years of Jacques Besson, Inventor of Machines, Teacher of Mathematics, Distiller of Oils and Huguenot Pastor," Technology and Culture, 14 (1973), 28-39.

20. On the state of Italian science, cf. Stillman Drake and I. E. Drabkin, eds., Mechanics in Sixteenth century Italy (Madison: University of Wisconsin Press, 1969), pp. 3-60; Christopher Lewis, The Merton Tradition and Kinematics in Late Sixteenth and Early Seventeenth Century Italy (Padua: Antenore, 1980); Jean Dietz Moss, Novelties in the Heavens: Rhetoric and Science in the Copernican Controversy (Chicago, University of Chicago Press, 1993); Mario Biagoli, Galileo, Courtier: The Practice of Science and the Culture of Absolutism (Chicago: University of Chicago Press, 1993), pp. 1-9. 
21. (Orléans: P. Trepperel, 1569).

22. Ibid., f. sig. Bi r.

23. Cf. Allan G. Debus, The French Paracelsians: The Chemical Challenge to Medical and Scientific Tradition in Early Modern France (New York: Cambridge University Press, 1991); Karen M. Reeds, Botany in Medieval and Renaissance Universities (New York: Garland, 1991); Giovanni Oleon Cifoletti, "Mathematics and Rhetoric: Peletier and Gosselin and the Making of the French Algebraic Tradition," unpublished Ph.D dissertation, Princeton University, 1992; R. Hooykaas, Humanisme, science et réforme: Pierre de la Ramée, 1515-1572 (Leiden: E. J. Brill, 1958).

24. In fact the great majority of those identified as followers of Copernicus prior to Galileo were Protestants. Cf. Westman, p. 85.

25. Ramus' relationship to Copernicanism is discussed in Hooykaas, Ibid.,pp. 64-74; Hooykaas, G. J. Rheticus' Treatise on Holy Scripture and the Motion of the Earth (Amsterdam, Oxford, New York: North-Holland Publishing, 1984), pp. 157-163.

26. Jean Dupèbe, "Autour du Collège de Presles: Testaments de Ramus, Talon et Pena," Bibliothèque d'Humanisme et Renaissance, 42 (1980), 129-130.

27. Euclidis Optica et Catoptrica (Paris, 1557), ff. aa iv.'. bbr.

28. On Pena's astronomy cf. Hooykaas, Humanisme, science et réforme, pp. 47-48; Lynn Thorndike, A History of Magic and Experimental Science (New York: Columbia University Press, 1941), VI, pp. 19-20.

29. Dupèbe, pp. 124-129.

30. Audomari Talori Academia. Ejusdem in academicum Ciceronifragmentum explicatio. Item in Lucullum commentarii (Paris: M. Dividis, 1550), f. 104: "Nicolaus Copernicus hisce nostris temporibus veterem illam opinionem sequutus de motu terrae multos libros scripsit ubi probat terra mota et coelo quiescente theoricam de stellis multo certiorem tradi quam si secus accidat."

31. On Talon's philosophical position cf. Charles B. Schmitt, Cicero Scepticus: A Study of the Influence of the Academics in the Renaissance (The Hague: Martinus Nijhoff, 1972), pp. 81-91.

32. Les Dialogues de Guy de Brues contre les nouveaulx academiciens (Paris: G. Cavellat, 1557). Cf. The Dialogues of Guy de Bruès, ed. Paul Morphos (Baltimore: Johns Hopkins University Press, 1953), pp. 3-84; Thomas Greenwood, "L'apologétique rationnelle de Guy de Bruès," Revue d'histoire philosophique et religieuse, 36 (1956), 20-49; Greenwood, "Guy de Bruès," Bibliothèque d'Humanisme et Renaissance, 13 (1951), 70-82, 172-186, 266-269; Richard H. Popkin, The History of Scepticism from Erasmus to Spinoza (Berkeley: University of California Press, 1979), pp. 30-32; Schmitt, pp. 102-108.

33. The Dialogues of Guy de Bruès, p. 149.

34. Cf. Frances A. Yates, The French Academies of the Sixteenth Century (London: Warburg Institute, 1947), p. 96. 
35. Schmitt, p. 103.

36. Discussed in Plattard, p. 234; Waldemar Voisé, "Montaigne et Copernic," in Avant, avec, après Copernic: la représentation de l'univers et ses conséquences épistémologiques, ed. Centre International de Synthèse (Paris: Albert Blancher, 1975), pp. 165-168.

37. Cf. Yates, pp. 14-30; Édouard Frémy, Origines de l'Académie française: l'Académie des derniers Valois (Paris: E. Leroux, 1887), pp. 27-82.

38. Cf. John C. Lapp, "Pontus de Tyard and the Science of His Age," Romanic Review, 38 (1947), 16-22; Sylviane Bokdam, "La poésie astronomique de Pontus de Tyard," Bibliothèque d'Humanisme et Renaissance, 38 (1986), 653-670; Thorndike, VI, pp. 24-26; Yates, pp. 9698; Jacqueline Boucher, Société et mentalités autour de Henri III (Lille: Université de Lille III, Atelier de reproduction des thèses, 1981), III, pp. 927-928.

39. On the development of a reformed astrology cf. Pontus de Tyard, Mantice: Discours de la verité de divination par astrologie, ed. Bokdam (Geneva: Droz, 1990), pp. 12-22.

40. Mantice, pp. 106-107.

41. St. Le Tourneur, “Augier Ferrier,” DBF, XIII, p. 1119; Richard Cooper, "Deux médecins royaux onirocritiques: Jean Thibault et Augier Ferrier," in Françoise Charpentier, ed. Actes du colloque international de Cannes 29-31 mai 1987: Le songe à la Renaissance (SaintÉtienne: Publications de l'Université de Saint-Étienne, 1987), pp. 56-57; Thorndike, VI, pp. 479-480.

42. Advertissements à M. Jean Bodin (Paris, 1579).

43. Ibid., f. 46. The work of the astrologer of the Duke of Anjou Francesco Giuntini represents another example of the link between interest in astrology and Copernicanism. Cf. G. McCalley, "Francesco Giuntini and the Copernican Hypothesis," Popular Astronomy, XLV (1937), 70-73.

44. For an account of the career of Candale, cf. Jean Ellen Harrie, "François Foix de Candale and the Hermetic Tradition in Sixteenth Century France," unpublished dissertation, University of California, Riverside, 1975.

45. Ibid., pp. 187-190; Westman, "Magical Reform and Astronomical Reform: The Yates Thesis Reconsidered" in Hermeticism and the Scientific Revolution: Papers Read at the Clark University Seminar, March 9, 1974 (Los Angeles: William Andrews Clark Memorial Library, University of California, Los Angeles, 1977), p. 43.

46. The Neo-Platonist Louis Le Roy, for example, saw in the displacement of the earth from the centre of the world a portent of disaster. Cf. Jean Céard, La nature et les prodiges: l'insolite au XVI siècle en France (Geneva: Droz, 1977), p. 381.

47. Edward A. Gosselin, “Bruno's 'French Connection': A Historiographical Debate," in Alan G. Debus and Ingrid Merkel, eds., Hermeticism and the Renaissance: Intellectual History and the Occult in Early Modern Europe (Washington: The Folger Shakespeare Library, 1988), p. 168.

48. Bruno's arguments were delivered by his student Jean Hennequin. Cf. Jordani Bruni Nolani Opera Latine Conscripta, ed. F. Fiorentino (Naples and Florence, 1879-1891; Stuttgart-Bad 
Gannstatt, 1962), I, pp. 55-71; L. Auvray, "Giordano Bruno à Paris d'après le témoignage d'un contemporain, 1585-1586," Mémoires de la Société d'histoire de Paris et de l'île-deFrance, I (1900), 288-301.

49. Frances A. Yates, Giordano Bruno and the Hermetic Tradition (Chicago: University of Chicago Press, 1964), pp. 155, 168, 194.

50. Westman, pp. 11, 27; McMullin, "Bruno and Copernicus," Isis, 78 (1987), p. 68.

51. On this particular question cf. Frances A. Yates, "The Religious Policy of Giordano Bruno," in Lull and Bruno: Collected Essays, vol. I (London: Routledge Kegan Paul, 1982), pp. 151 179. Bruno as a secret English agent is the theme of John Bossy's Giordano Bruno and the Embassy Affair (New Haven: Yale University Press, 1991).

52. Yates, The French academies, pp. 230-234.

53. I have used the discussion of Copernicus found in the critical edition of the translation of the Six Books of the Commonwealth by Richard Knolles, edited by Kenneth Douglas McCrae (Cambridge: Harvard University Press, 1962), pp. 453-455.

54. René Herpin, Apologie pour la republique de Jean Bodin (Paris, 1583), ff. 29-30r.

55. (Lyon: I. Rossin, 1596), pp. 581-582.

56. Cf. Ann M. Blair, "Restaging Jean Bodin: The Universae Naturae Theatrum (1596) in its Cultural Context," unpublished dissertation, Princeton University, 1991, pp. 221-228.

57. Bodin claims that Copernicus attributed four natural motions to the earth -- diurnal, annual, trepidary and gravitational. In fact, Copernicus' fourth motion was not gravitational but rather a motion of the axis of rotation.

58. Simone Goyard-Fabre, Jean Bodin et le droit de la république (Paris, Presses Universitaires de France, 1989), p. 276.

59. Six Books of the Commonwealth, p. 454; Apologie pour la republique de Jean Bodin, f. 30v.

60. Apologie pour la republique de Jean Bodin, ff. $29^{\vee}-30^{\text {r }}$.

61. Cf. L. W. B. Brockliss, "The Scientific Revolution in France," in Roy Porter and Mikulas Teich, eds., The Scientific Revolution in National Context (Cambridge: Cambridge University Press, 1992), pp. 11-54.

62. Margaret C. Jacob, The Cultural Meaning of the Scientific Revolution (New York: Knopf, 1988), pp. 43-69.

63. Henry Heller, Labour, Science and Technology in France, 1500-1620 (Cambridge: Cambridge University Press, 1995).

64. For a balanced discussion of the relation between a contextual and internalist view of the history of science cf. H. F. Cohen, The Scientific Revolution: A Historiographical Inquiry (Chicago: University of Chicago Press, 1994), pp. 198-200.

65. Porter and teich, The Scientific Revolution, p. 2.

66. Cf. Stephen A McKnight, Science, Pseudo-science and Utopianism in Early Modern Thought (Columbia, MO: University of Missouri Press, 1992), pp. viii-x. 
26 / Renaissance and Reformation / Renaissance et Réforme

67. Robert S. Westman, "Proof, poetics and Patronage: Copernicus's Preface to $D e$ Revolutionibus," in David C. Lindberg and R. S. Westman, eds., Reappraisals of the Scientific Revolution (Cambridge: Cambridge University Press, 1990), pp. 167-205; Moss, Novelties in the Heavens, pp. 27-64.

68. William Eamon, Science and the Secrets of Nature: Books of Secrets in Medieval and Early Modern Culture (Princeton: Princeton University Press, 1995). 